\title{
Characterization for the necessity of thermophilic biogas digester of tea waste and cooked waste for biogas production
}

\author{
Nirmal Halder \\ Department of Mechanical Engineering, Indian Institute of Technology Kanpur, India
}

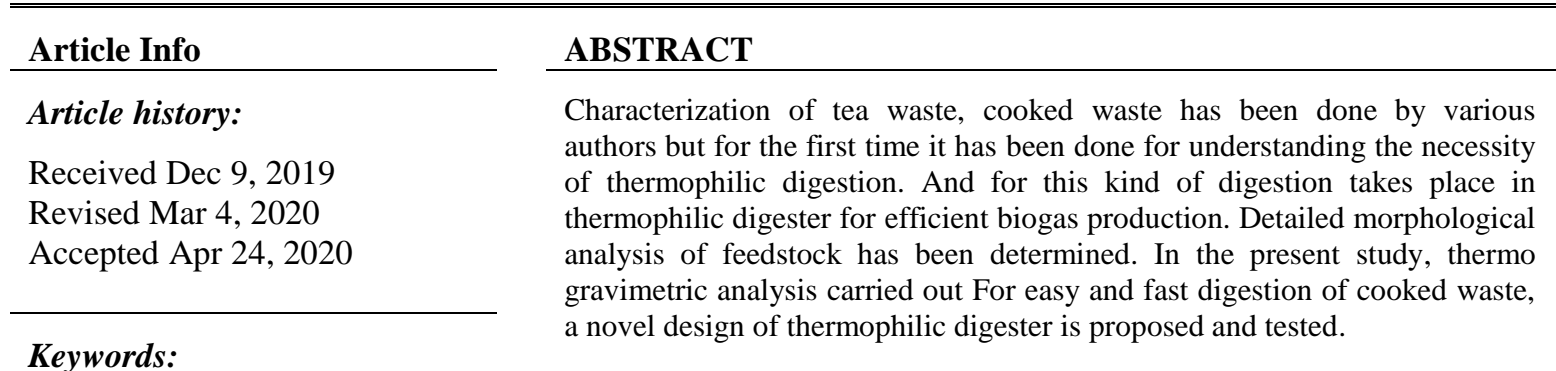

Biogas

Cooked waste

Tea waste

Thermophilic digester

This is an open access article under the $\underline{C C B Y-S A}$ license.

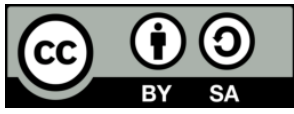

\section{Corresponding Author:}

Nirmal Halder,

Departement of Mechanical Engineering,

Indian Institute of Technology Kanpur, India.

Email: subho.nirmal@gmail.com

\section{INTRODUCTION}

Bio energy production from local bio resources has a great potential. It is important to reduce dependency on fossil fuels and decrease green house gas emission.Tea plants (Camellia sinensis) are commonly grown in the north east region of India. High quality tea is harvested from the three top leaves of the shoot on tea plant in the tea garden. While tea producer cut the top tea leaves with special tea shears, some overgrown woody shoots, which may include six-seven top leaves, are mixed in the tea harvest. During the tea production procedure, this woody overgrown shoots are not treated by tea factory and formed into tea waste. Tea manufacturing industries throw out lots of waste teas, daily, as left over. According to Tea Waste (Control) Order1959, every tea manufacturing unit should declare at least $2 \%$ of its production as tea waste [1]. Approximately 857,000 tonnes of tea is produced in India per year, which is $27.4 \%$ of total world production. After processing, tea factory waste is about 190,400 tonnes [2]. Assam, situated in the north east region of India is the single largest contagious tea growing area in the world and as such is the hub for bulk production of tea waste. Cooked waste is another high moisture content waste produced in bulk in every locality.

Anaerobic digestion has been suggested as a promising technique for pollution reduction when used for energy production from waste [3-7]. In the present study the potential of cooked waste has been assessed for biogas production and compared with that of cow dung. Cooked waste is produced in bulk in every locality. Sung et al. [8] evaluated both chronic and acute toxicity of ammonia in thermophilic anaerobic digestion of synthetic wastewater over a range of acclimation concentrations. Experimentally gavala et al. [9] Investigates (a) the differences between mesophilic and thermophilic anaerobic digestion of sludge and (b) the effect of the pretreatment at 70 degree Centigrades on mesophilic and thermophilic anaerobic digestion of 
primary and secondary sludge. Demirel et al. [10] investigated that even though ammonia is an essential nutrient for bacterial growth, it may inhibit methanogenesis during anaerobic digestion process if it is available at high concentrations. The tolerance of the biogas process under supply of hydrogen, to ammonia toxicity was studied under mesophilic and thermophilic conditions by wang et al. [11]. Ahring et al. [12]. Investigated that oleate is the free fatty acid that influences the bacterial activity under mesophilic and thermophilic conditions. Zeshan et al. [13] studied the effect of ammonia-N accumulation in a dry anaerobic digestion was studied effectively using pilotscale thermophilic reactor. Biomass samples taken during the continuous operation of thermophilic anaerobic digestors fed with manure and exposed to successive inhibitory pulses of long-chain fatty acids by palatsi et al. [14].

\section{RESEARCH METHOD}

Three samples (Tea waste, cooked wasteand cow dung), are used in the present work. The surface characteristics of the biomasses areanalyzed by using SEM (Scanning Electron Microscope). The heating values of the samples are measured for combustion in an adiabatic oxygen bomb container as per IP-12 and IS-1305. Thermo gravimetric analysis (TGA) is performed on a Metter TGA/SDTA 851 Thermo gravimetric analyzer. COD values of different samples are determined by the modified open reflux method (APHAAWWA-WPCF) as described by Yadvika et al. [15], which are suitable for samples with high percentage of suspended solids. The Biological Oxygen Demand (BOD) determination is an empirical test in which standardized laboratory procedures are used to determine the relative oxygen requirements of waste waters, effluents and polluted waters.For heating value, thermo gravimetric, biological oxygen demand analyses following equations are used.

Percentage of Total solid $=[\{($ Weight of dry pan + dry sample $)-$ Weight of dry pan $\} /$ Weight of sample as received]x 100

Percentage of Moisture $=100-$ percentage of Total solid

Percentage of $\mathrm{Ash}=[\{($ Weight of crucible + ash $)-$ weight of crucible $\} /$ Oven dry weight of sample] $\mathrm{x} 100$

Volatile content $=[(\mathrm{m} 2-\mathrm{m} 3) /(\mathrm{m} 2-\mathrm{m} 1)] \times 100$

Where $\mathrm{m} 1$ is mass of the empty crucible with the lid, $\mathrm{m} 2$ is mass of the crucible with lid and the sample before heating, $\mathrm{m} 3$ is mass of the crucible with lid and the sample after heating.

Fixed carbon $=100-$ ash - water content $($ moisture $)-$ volatiles

Percentage of Lignin $=\%$ AIL $+\%$ ASL

where AIL is acid insoluble lignin, ASL is acid soluble lignin

Heating Value $=($ WE $x$ Temperature rise $) /$ Sample weight

where WE is the water equivalent $=2568.293$ and $\mathrm{T}$ for differential temp.

Chemical oxygen demand, $(\mathrm{COD})$ in $\mathrm{mg} / \mathrm{l}=\{(\mathrm{A}-\mathrm{B}) \times \mathrm{M} \times 8000\} / \mathrm{V}$

where, A is avolume of blank titrant $(\mathrm{ml}), \mathrm{B}$ is a volume of sample titrant ( $\mathrm{ml}), \mathrm{M}$ is the molarity of FAS solution= [Volume $0.04167 \mathrm{M} \mathrm{K2Cr2O7} \mathrm{Solution} \mathrm{titrated,} \mathrm{ml} \mathrm{/Volume} \mathrm{FAS} \mathrm{used} \mathrm{in} \mathrm{titration,}$ $\mathrm{ml}] \times 0.2500$

$8000=$ mill equivalent weight of oxygen $\times 1000 \mathrm{ml} / 1$

And $V=(D 2-D 1) / P$

Where $\mathrm{Y}$ is the mass of the dry solid sample used for analysis, $\mathrm{X} 1$ is the volume of original slurry sample used for drying, $\mathrm{X}$ is the solid content of $\mathrm{X} 1 \mathrm{ml}$ of the slurry sample. Thus $\mathrm{V}$ is the volume in $\mathrm{ml}$ of original slurry, which would have contained Y grams of the dry solids. 
Where D1is the DO (Dissolved Oxygen) of diluted sample immediately after preparation in $\mathrm{mg} / \mathrm{l}$, D2 is the DO of diluted sample immediately after 5 days incubation at $200 \mathrm{C}$ in $\mathrm{mg} / \mathrm{l}, \mathrm{P}$ is the decimal volumetric fraction of sample used.

\section{RESULTS AND DISCUSSION}

\subsection{Moisture content}

Moisture content increases the crystallinity of cellulose as described by Taherzadehet al. [16]. Due to crystallization of highly amorphous cellulose hydrolysis process, which is a very prominent process for biogas production, becomes very difficult. So higher moisture content represents low biodegradability. In other word higher moisture content increases the time requirement for the digestion as well as for the biogas production. Figure 1 shows that cooked waste has very high moisture content (44.99\%) as compared to tea waste $(12.06 \%)$ and cow dung $(9.88 \%)$. So instead of ordinary mesophilic biogas digester we need an efficient thermophilic biogas digester which will decrease the time requirement for the digestion of cooked waste and tea waste.

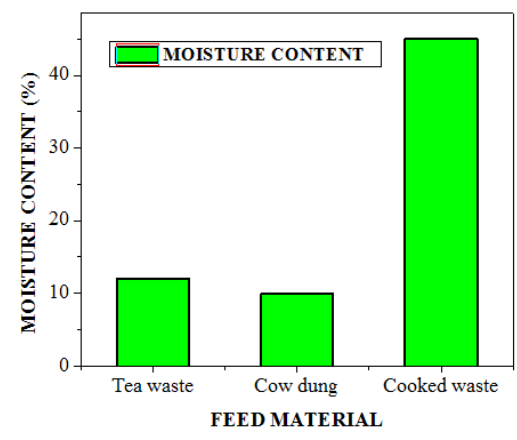

Figure 1. Moisture content

\subsection{Fixed carbon content}

Fixed carbon is the solid combustible residue that remains after a biomass particle is heated and the volatile matter is expelled. The fixed-carbon content of a biomass is determined by subtracting the percentages of moisture, volatile matter and ash from a sample. Since gas to solid combustion reactions are slower than gas to gas reactions, a high fixed-carbon content indicates that the biomass will require a long time to produce combustible biogas and at the same time biomass will produce higher amount of combustible biogas. For this reason cow dung produces combustible biogas, faster than cooked waste. Cooked waste requires a long time for digestion. The fixed carbon content is higher in tea waste $(18.31 \%)$ and cooked waste $(15.08 \%)$, as compare to cow dung $(11.57 \%)$ as depicted in Figure 2. So we need to design \& develop an efficient thermophilic digester to produce combustible biogas from cooked waste and tea waste in a less time. Thermophilic digestion requires less time for producing combustible biogas, than mesophilic digestion process. Hence for a faster digestion of cooked waste we have to prefer thermophilic digestion instead of mesophilic digestion.

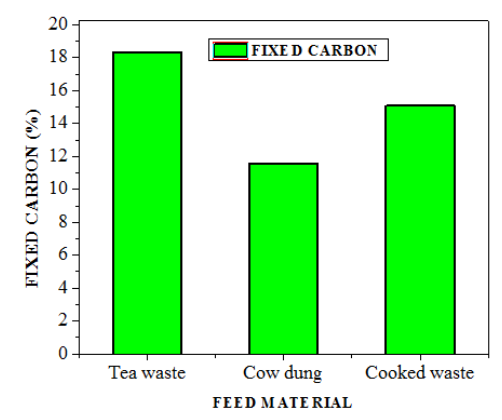

Figure 2. Fixed carbon content

Characterization for the necessity of thermophilic biogas digester of tea waste and cooked (Nirmal Halder) 


\subsection{Lignin content}

The effect of lignin content on the biodegradability seems to be linear and is inspected that for every one percentincrease of lignin the biodegradability drops by about 3\% [17]. It is observed from lignin content analysis for biomass that, increase in lignin content in biomass, increases time requirement for digestion. The lignin content in cooked waste and tea waste is near about identical (28.56\%), which is higher than cow dung $(19.8 \%)$ as shown in Figure 3. From lignin content analysis it is quite explicit that, here also we need to develop a digester in which a thermophilic digestion will takes place for proper \& quicker digestion of cooked waste.

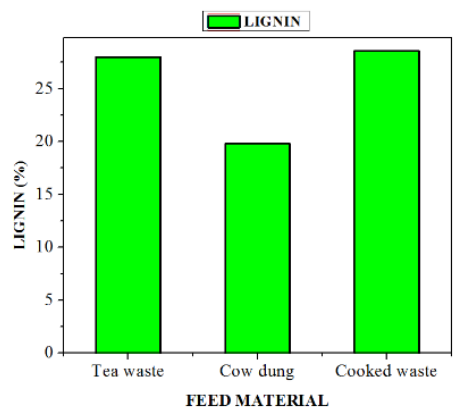

Figure 3. Lignin content

\subsection{SEM (scanning electron microscopy) analysis}

Lignocellulosic materials have two different types of surface area, external and internal. The external surface area is related to the size and shape of the particles, while the internal surface area depends on the capillary structure of cellulosic fibers. There is a good correlation between the accessible surface area and the enzymatic digestibility of Lignocellulosic materials [18]. Figure 4 shows the external surface morphology of the feed stock. It has been observed that the surface morphology of cow dung is highly porous mass with easy accessibility for digestion. The morphology of cooked waste looks like a compact globular mass of multiple units with hollow grooves and minute pores enhances difficulty for digestion. The morphology of tea waste is observed as a mass of compact fibers with tunnels, intermittent grooves and minute pores. From SEM analysis it has been observed that cow dung is easily digestible but for a proper and quicker digestion of cooked waste we have to design $\&$ develop a thermophilic biogas digester.

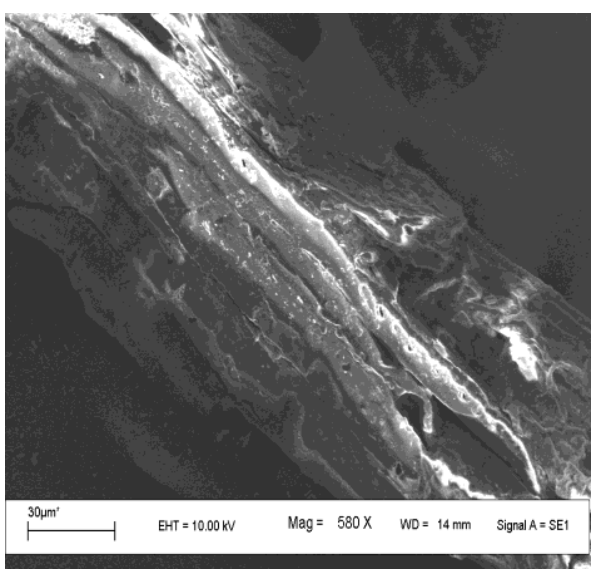

(a)

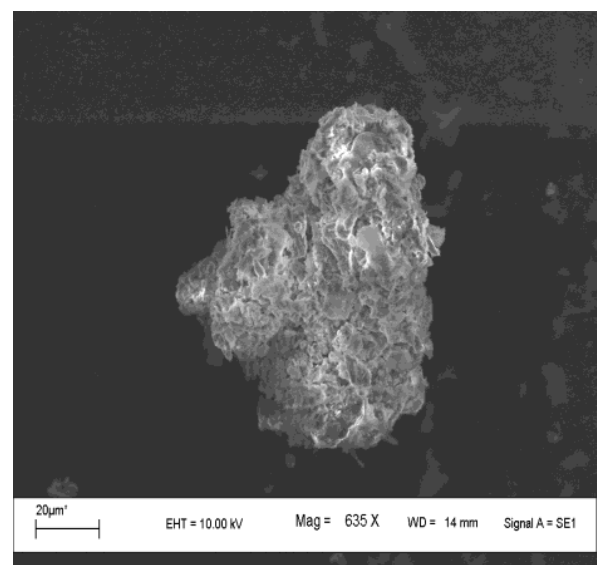

(b) 


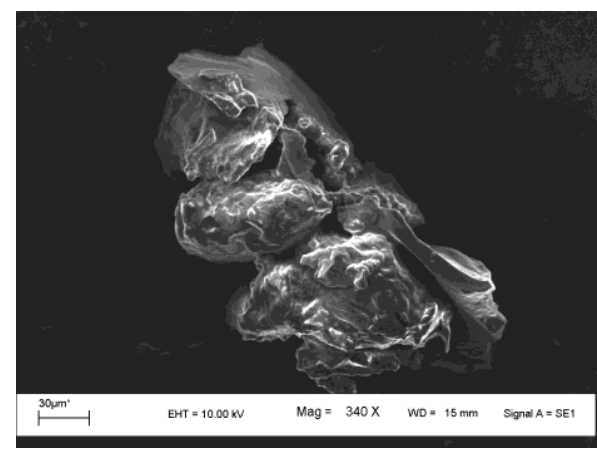

(c)

Figure 4. SEM images of tea waste (a), cow dung (b), cooked waste (c)

\subsection{TGA (Thermo gravimetric analysis)}

TGA (Thermo gravimetric analysis) of the feed stock was performed to determine temperature points and ranges where devolatilization of biomass occurs, which provides qualitative and quantitative information regarding the organic content of the sample [19]. The higher the temperature at which weight loss occur, the more resistant is the organic fraction which is burning [20]. TGA curves have been represented in terms of the percentage of the weight loss experienced by the sample in Figure 5. The first loss of weight registered at low temperatures is associated with dehydration of the samples. A broad curve is observed for cooked waste followed by tea waste due to its high moisture content as mentioned earlier. Thus, to increase the enzymatic digestibility of cooked waste its moisture content would have to be reduced to appreciable amount. And this reduction is possible only with an efficient thermophilic type biogas digester.

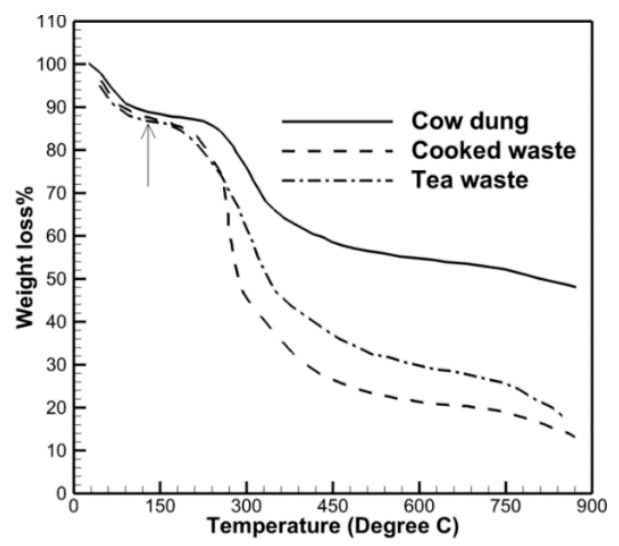

Figure 5. TGA profile

\subsection{Heating value}

The heating value of biomass is dependent on the amount of organic content. Heating value is superior where lower resistance is offered by the organic fraction. As discussed earlier, resistance appears from moisture, hemicelluloses, cellulose, lignin content $\&$ inaccessible internal surface area. Heating value is higher for cooked waste $(15.265 \mathrm{kj} / \mathrm{gm}) \&$ tea waste $(27.62 \mathrm{~kJ} / \mathrm{gm})$ as compared to cow dung $(8.922 \mathrm{~kJ} / \mathrm{gm})$ as shown in Figure 6. So from above mentioned heating value analysis we can conclude that a high heating value is needed for cooked waste for the complete \& quicker digestion. In order to achieve complete \& quicker digestion, we have to prefer for thermophilic digestion. For thermophilic digestion an innovative thermophilic digester is chosen. 


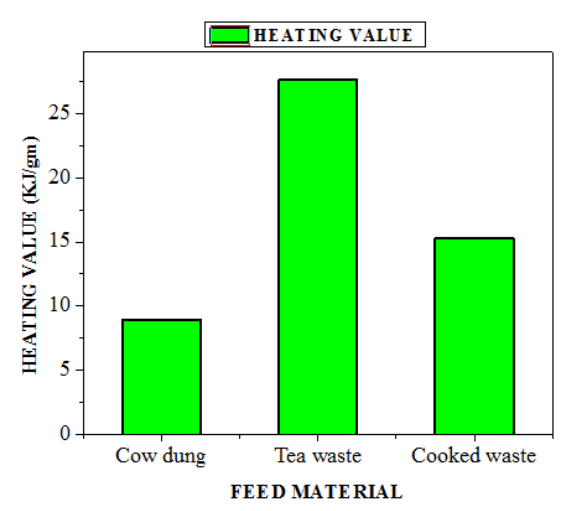

Figure 6. Heating value

\subsection{COD value}

It is found that cooked waste has the highest COD value followed by tea waste and cow dung, as indicated by the Figure7. Cow dung consists of simple monomers, which are easily biodegradable as compared to cooked waste. Cooked waste and tea waste consists of hemicelluloses, cellulose and lignin. Hence, a high COD for cooked waste indicates its potentiality for biogas production. And for easily biodegradable digestion of cooked waste an efficient thermophilic biogas digester is needed to be designed \& developed.

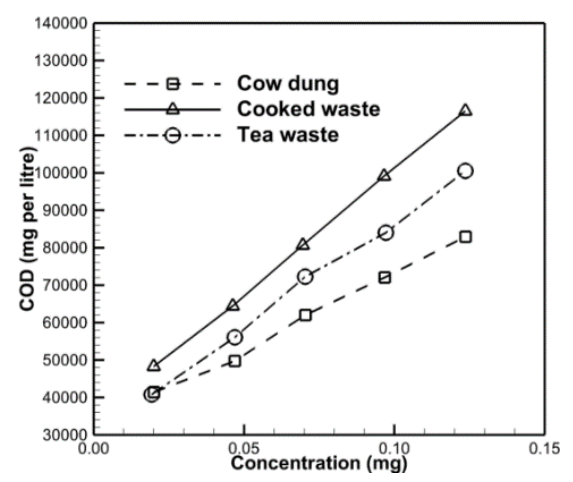

Figure 7. COD content

\subsection{Necessity of novel design of thermophilic digester}

From the above analysis of moisture content, fixed carbon content, heating value, TGA, COD, lignin content, scanning electron microscope (SEM) it is very clear that cooked waste and tea waste requires a long time to produce combustible biogas and are not easily digestible as compared to cow dung. And for efficient biogas production from tea waste and cooked waste we have to maintain a thermophilic digestion.Design parameter for thermophilic biogas digester:

- Active slurry Volume of digester

- Gas production rate

- $\quad$ Amount of feed material fed into the digester

- Total initial feeding

- $\quad$ Slurry displacement volume

With above-mentioned design parameter a thermophilic biogas digester is developed. The digestion of manure occurs in four basic stages as mentioned below:

First step

The organic matter (carbohydrates, proteins, lipids) is hydrolysed to soluble compounds (amino acids and sugars) with the aid of cellulytic proteolytic lypolytic bacteria.

Second step 
The soluble compounds (amino acids and sugars) are fermented into volatile fatty acids in the presence of fermentive bacteria

Third step

Fermentation-acetogenesis forms hydrogen, carbon dioxide and acetate from fatty acid with the help of hydrogen producing bacteria

Fourth step

Methanogenic bacteria produce biogas (consist of methane and carbon dioxide) from acetates and hydrogen by methanogenesis process.

Comparison between Mesophilic and Thermophilic digestion with cow dung, tea waste and cooked waste (cow dung: cooked waste $=1: 1$ in quantity) [21].

Thermophilic digestion comprises with higher temperature as compare to mesophilic digestion [21]. Range of production of combustible gas for mesophilic digestion varies from $0.005904 \mathrm{~m} 3$ to $0.006232 \mathrm{~m}^{3}$ and range of production for thermophilic varies from $0.0072 \mathrm{~m}^{3}$ to $0.0076 \mathrm{~m}^{3}$. So almost $22 \%$ increase in gas production is observed for thermophilic digestion as compared to mesophilic digestion. Although mesophilic digestion gives biogas comprises with higher methane content as compare to thermophilic digestion temperature, but at the same time low digestion temperature (mesophilic digestion) produce less amount of biogas. For the accomplishment of hydrolysis process (First step of digestion process) thermophilic digestion takes more time. So thermophilic digestion takes more time to produce methane and carbon dioxide. That is why it is noticed that, combustible gas production starts from 11th day onwards for mesophilic digestion, whereas for thermophilic it starts from 14th day onwards. Comparison in per day gas production, with feed material as cow dung and cooked waste in the ratio of 1:1 in quantity, for mesophilc and thermophilic digestion, has been shown in the Figure 8-(a). Also feed material as cow dung and tea waste in the ratio of 1:1 in quantity, for mesophilc and thermophilic digestion, has been shown in the Figure 8-(b). It is observed that, combustible gas production starts from 8th day onwards for mesophilic digestion, whereas for thermophilic it starts from10th day onwards.So at the conclusion we can say that although mesophilic digestion produce less amount of biogas, but the gas becomes combustible quicker than thermophilic digestion due to higher methane content. Effect on thermophilic digestion for the quantity variation of cooked waste and tea waste [21].

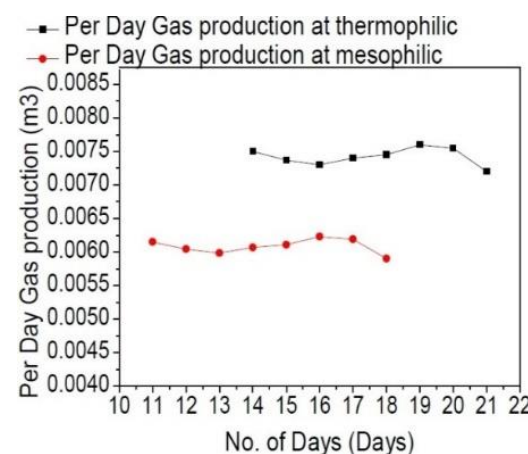

(a)

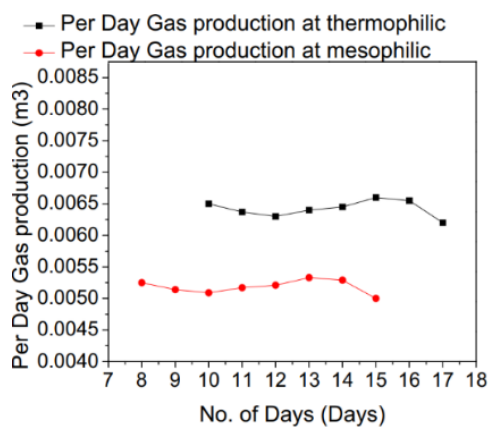

(b)

Figure 8. (a). Comparison between Mesophilic and Thermophilic digestion with cow dung and cooked waste (cow dung: cooked waste $=1: 1$ in quantity)

(b). Comparison between Mesophilic and Thermophilic digestion with cow dung and tea waste (cow dung: tea waste $=1: 1$ in quantity)

Performance of thermophilic digestion is inspected by varying the amount of cooked waste and tea waste in feed material. Effect on thermophilic digestion by gradual increment in cooked waste is observed. For the sake of simplicity various cases has been configured. For the first case (case1) cooked waste quantity is zero. In case 2 same amount of cooked waste and cow dung is taken for the mixture. Here proportion of cooked waste and cow dung is $1: 1$. Cooked waste quantity is 2 times higher than cow dung for case 3 . Here earlier mentioned proportion is $2: 1$. In case 4 proportional ratio is 2.5:0.5 for cooked waste and cow dung as shown in Figure 9-(a). For the case 4-(a) tea waste quantity is zero. Case 4-(a) is identical with case 1 in respect of waste quantity. In case 5 same amount of tea waste and cow dung is taken for the mixture. Here proportion of tea waste and cow dung is 1:1. Tea waste quantity is 2 times higher than cow dung for case 6 . Here earlier mentioned proportion is $2: 1$. In case 7 proportional ratio is 2.5:0.5 for tea waste and cow dung as shown in Figure 9-(b).

Characterization for the necessity of thermophilic biogas digester of tea waste and cooked (Nirmal Halder) 
For case 1 biogas production range is from $0.0042 \mathrm{~m}^{3}$ to $0.00455 \mathrm{~m}^{3}$. For case 2 it is $0.0072 \mathrm{~m}^{3}$ to $0.0076 \mathrm{~m}^{3}$ while for case 3 it is $0.0082 \mathrm{~m}^{3}$ to $0.0086 \mathrm{~m}^{3}$. Whereas biogas production ranges are from $0.008750 \mathrm{~m}^{3}$ to $0.009110 \mathrm{~m}^{3}$, for case 4 . For case 4-(a) biogas production range is from $0.0042 \mathrm{~m}^{3}$ to 0.00455 $\mathrm{m}^{3}$. For case 5 it is $0.0062 \mathrm{~m}^{3}$ to $0.0065 \mathrm{~m}^{3}$ while for case 6 it is $0.0072 \mathrm{~m}^{3}$ to $0.0075 \mathrm{~m}^{3}$. Whereas biogas production ranges are from $0.0077 \mathrm{~m}^{3}$ to $0.0080 \mathrm{~m}^{3}$, for case 7 .

If we compare biogas production between case 1 and case 2 , near about $70 \%$ increment is noticed in biogas production for case 2. While near about $13 \%$ increment is noticed in biogas production for case 3 as compared to case 2 . If biogas production comparison is made between case 4 and 3 , almost $6 \%$ increment in gas production is noticed for case 4. Due to oil and high moisture content in cooked waste, accomplishment time of hydrolysis process (First step of digestion process) is higher for thermophilic digestion. So thermophilic digestion takes more time to produce combustible biogas as shown in Figure 10. As we increase the quantity of cooked waste in feed material for thermophilic digestion, time requirement will increase for combustible biogas production. Less time requirement is noticed where presence of less amount of cooked waste in the feed stock for thermophilic digestion. For case 1 where thermophilic digestion takes place in the absence of cooked waste, combustible gas production starts from 12th day onwards. For case 2 (cooked waste: cow dung $=1: 1$ in quantity) it is 14 th day onwards. While for case 3 (cooked waste: cow dung $=2: 1$ in quantity) time requirement is 15th day onwards. And for case4 (cookedwaste: cow dung $=2.5: 0.5$ in quantity) time requirement is 16th day onwards. For case 4-(a) where thermophilic digestion takes place in the absence of tea waste, combustible gas production starts from 12th day onwards. For case 5 (tea waste: cow dung $=1: 1$ in quantity) it is 10 th day onwards. While for case6 (tea waste: cow dung $=2: 1$ in quantity) time requirement is 11th day onwards. And for case7 (tea waste: cow dung $=2.5: 0.5$ in quantity) time requirement is 12 th day onwards.

Comparison in per day gas production, due to changes in feed material for thermophilic digestion using cooked waste and cow dung. Comparison in per day gas production, due to changes in feed material (tea waste and cow dung) for thermophilic digestion, has been shown in the Figure 18-(b). Also time requirement for combustible biogas production in thermophilic digestion for the variation in cooked waste, tea waste quantity.

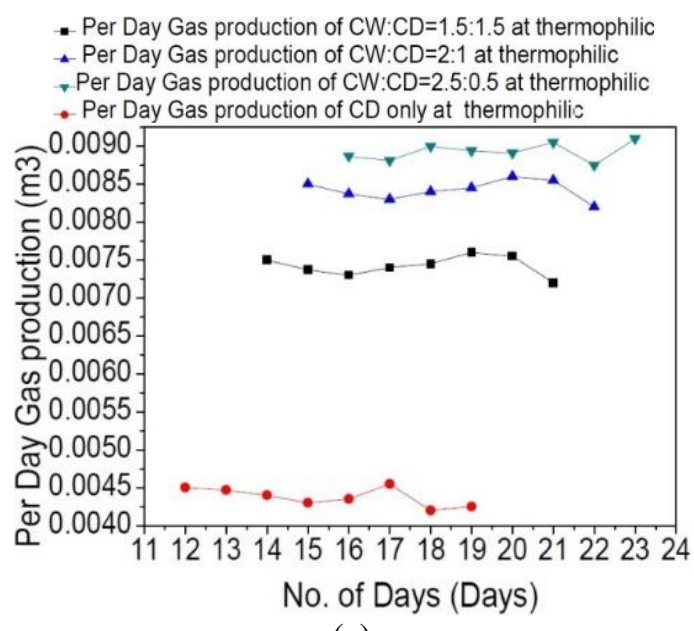

(a)

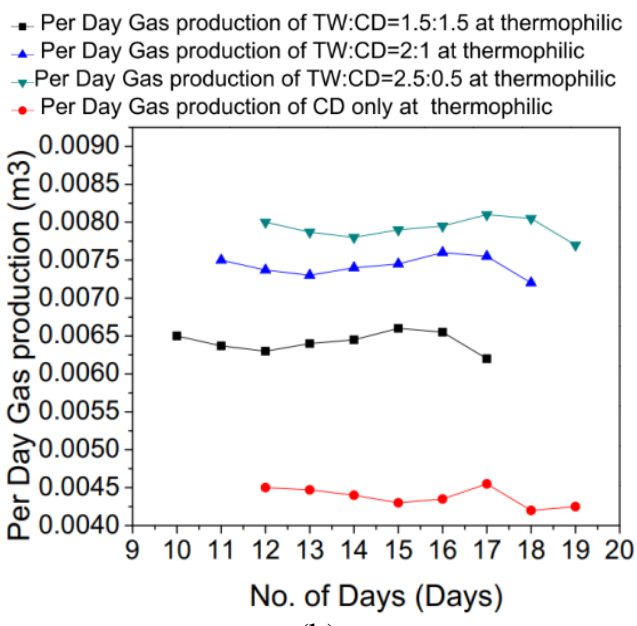

(b)

Figure 9. Comparison in feed material (a) cooked waste (CW) and cow dung (CD), (b) tea waste (TW) and cow dung $(\mathrm{CD})$ in thermophilic digestion 


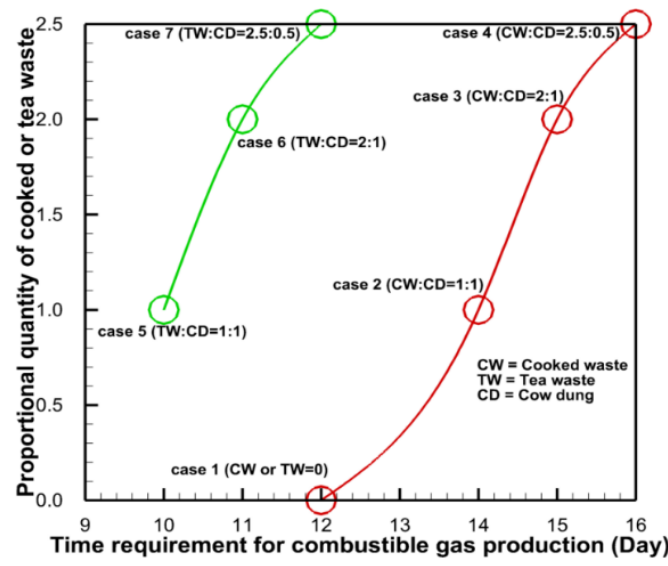

Figure 10. Time requirement for combustible biogas production in thermophilic digestion for the variation in cooked waste, tea waste, cow dung proportion

Simulation has been done with the help of ANSYS, mesh is created in ICEMCFD and simulation is performed with FLUENT adopting k-omega SST turbulence model. Here unsteady simulation is carried out considering the same geometry as explained in [21]. Unsteady simulated data (instantaneous quantity and time averaged quantity) is taken after reaching dynamic steady state as explained in Figure 11 [22]. Here various instantaneous and time averaged quantities is obtained within a cycle time period at four time instant (see Figure 13, Figure 14, Figure 15, Figure 16, Figure 17, Figure 18, Figure 19 and Figure 20 ). Through fast Fourier transformation we are getting strauhal number which is the reciprocal of cyclic time period as depicted in Figure 12. Various instantaneous quantities like instantaneous x velocity, y velocity, pressure, $q$ criteria are plotted in Figure 13, Figure 14, Figure 15 and Figure 16 respectively. Various time averaged quantities like mean x velocity, y velocity, pressure, Q criterio are plotted in Figure 17, Figure 18, Figure 19 and Figure 20 respectively. From mean y velocity distribution and pressure distribution it is quite clear that maximum y velocity and maximum pressure exists well above the outlet inside the digester. Q criteria with vector distribution expresses that generated biogas has swirling motion inside the digester. For breaking this swirling motion we need some paddle type arrangement which rotates inside the digester.

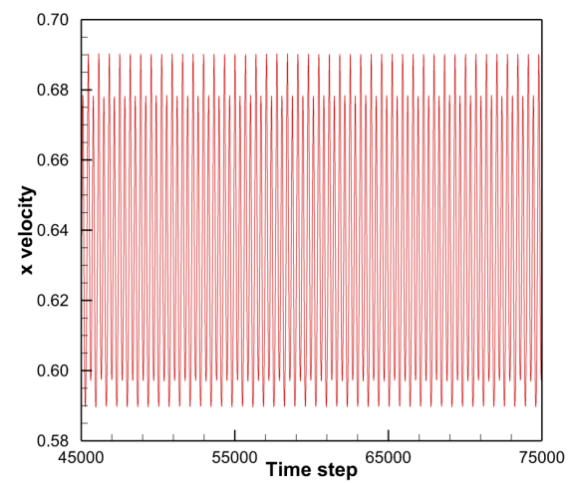

Figure 11. Signal of $x$ velocity for the location $1,1,0$

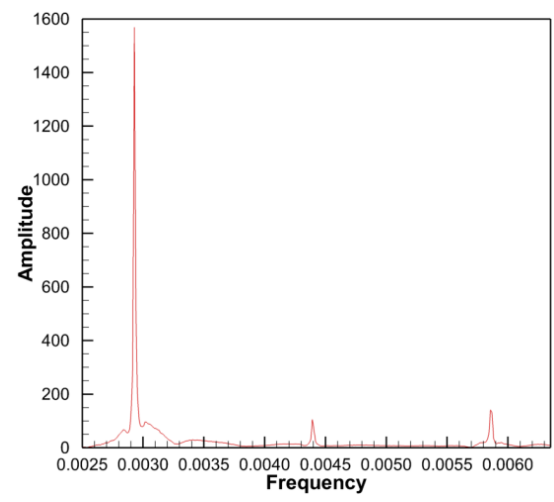

Figure 12. Fast Fourier transform 


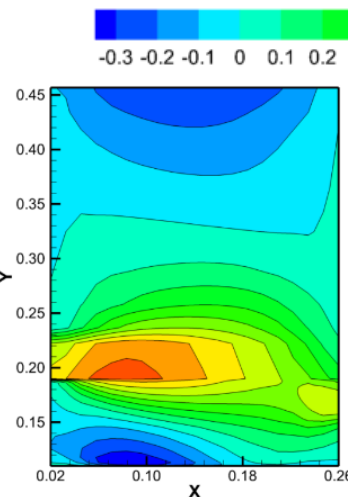

(a)

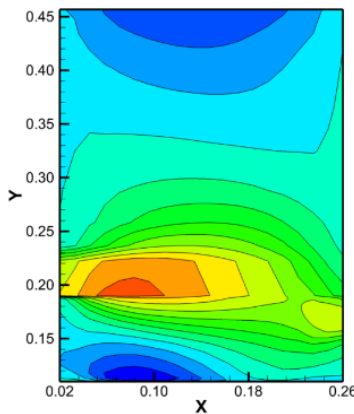

(c)

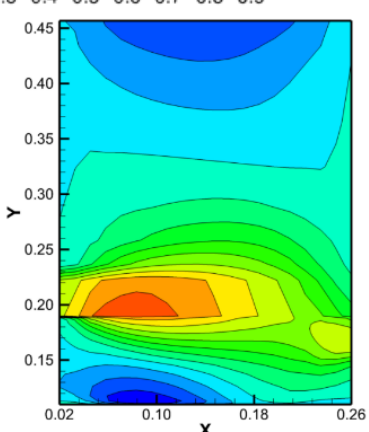

(b)

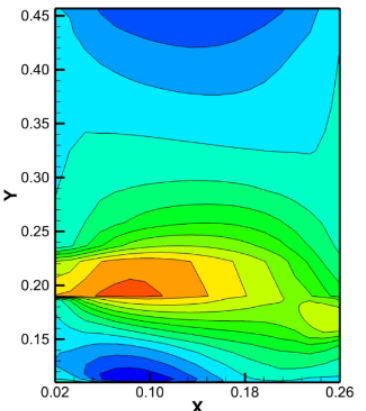

(d)

Figure 13. Instantaneous $X$ velocity at four time instant (a) $t=t_{a}$, (b) $t_{a}+1$, (c) $t_{a}+2$, (d) $t_{a}+3$

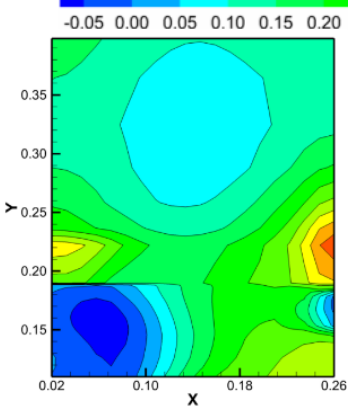

(a)

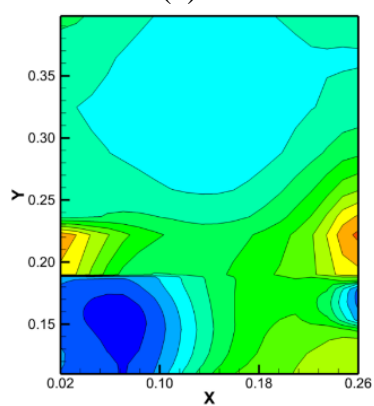

(c)

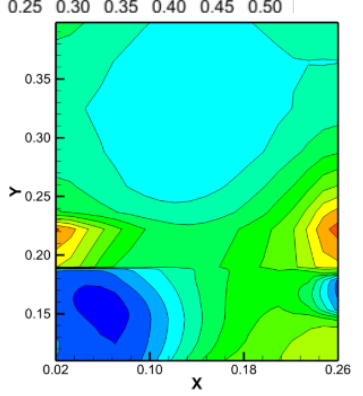

(b)

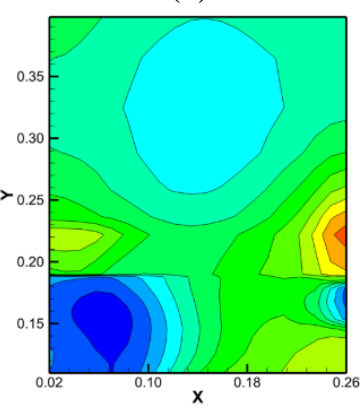

(d)

Figure 15. Instantaneous pressure at four time instant (a) $t=t_{a}$, (b) $t_{a}+1$, (c) $t_{a}+2$, (d) $t_{a}+3$
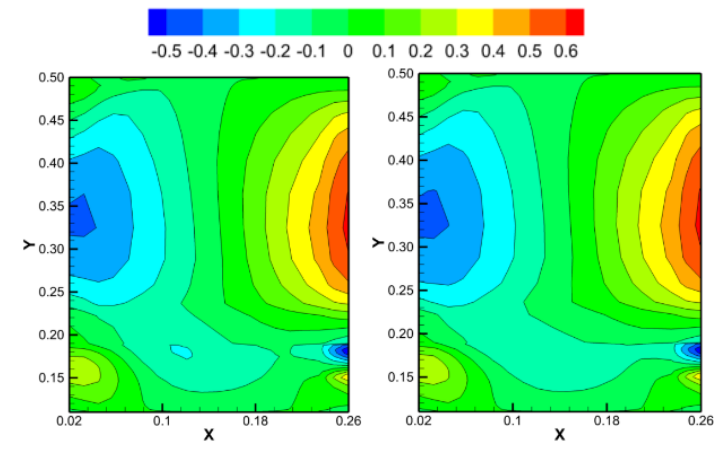

(a)

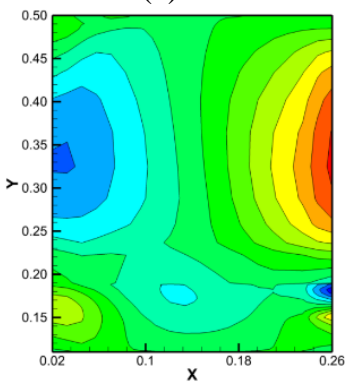

(c) (b)

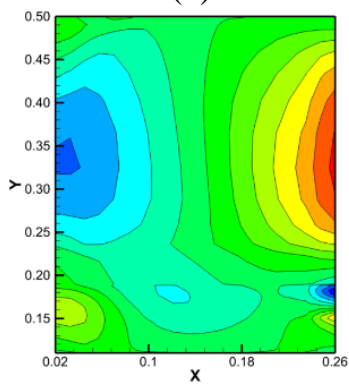

(d)

Figure 14. Instantaneous Y velocity at four time instant

(a) $t=t_{a}$, (b) $t_{a}+1$, (c) $t_{a}+2$, (d) $t_{a}+3$

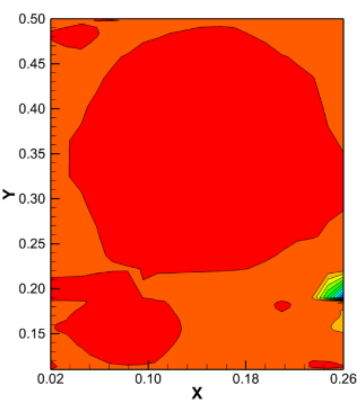

(a)

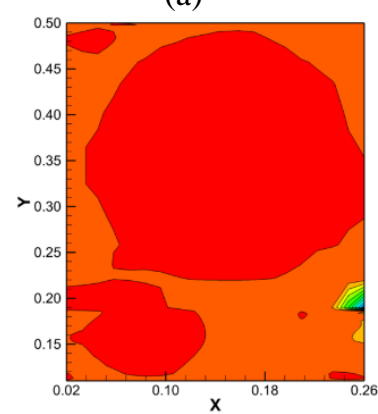

(c)

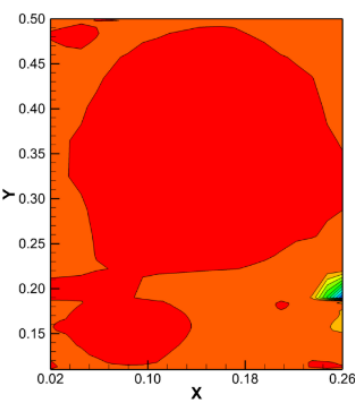

(b)

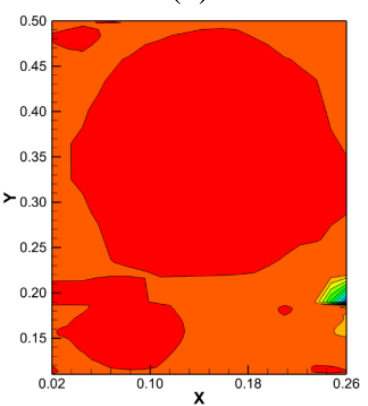

(d)

Figure 16. Instantaneous Q criteria at four time instant

(a) $\mathrm{t}=\mathrm{t}_{\mathrm{a}}$, (b) $\mathrm{t}_{\mathrm{a}}+1$, (c) $\mathrm{t}_{\mathrm{a}}+2$, (d) $\mathrm{t}_{\mathrm{a}}+3$ 


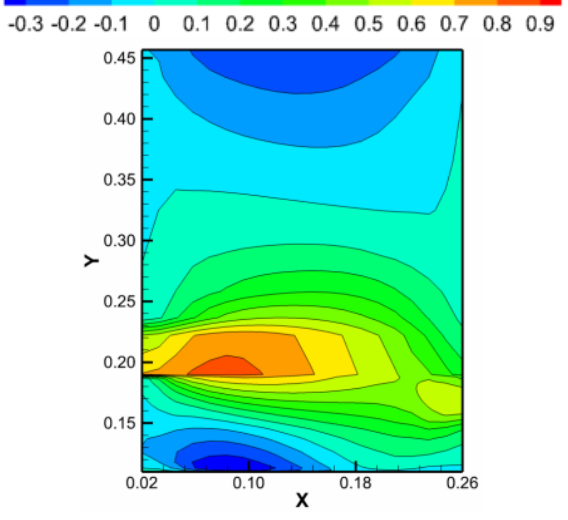

Figure 17. Time averaged $\mathrm{X}$ velocity

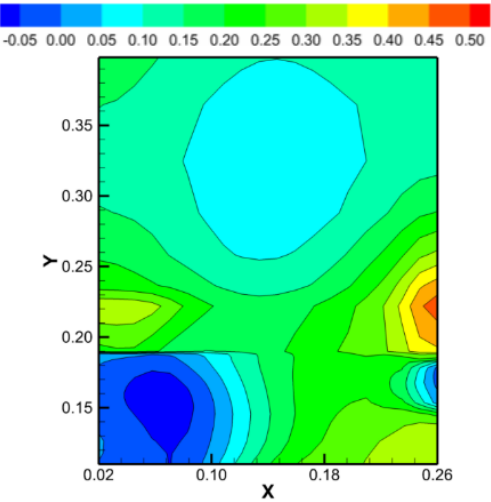

Figure 19. Time averaged pressure

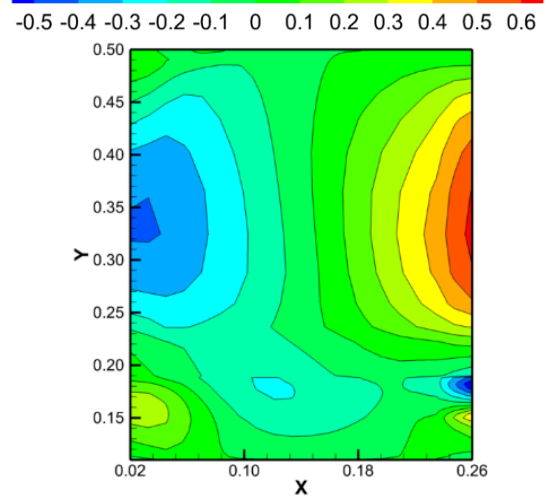

Figure 18. Time averaged Y velocity

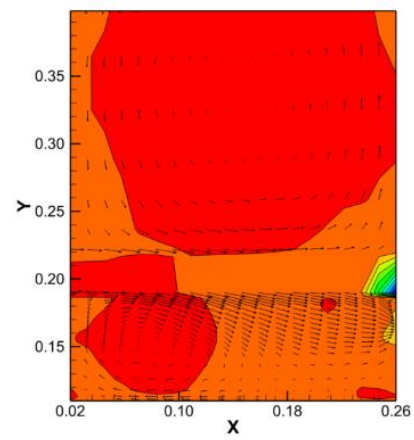

Figure 20. Time averaged Q criteria with velocity vector

\section{CONCLUSION}

Characterization of cooked waste and tea waste is evaluated including moisture content, fixed carbon content, lignin content, and observed that wastes (cooked waste, tea waste) requires a long time to produce combustible biogas and is not easily digestible as compared to cow dung. Hence for a faster digestion a new design of thermophilic digester is proposed and executed. Also performance analysis is carried out on this multi feed thermophilic digester implementing cook waste, tea waste and cow dung as a feed stock. It is inspected that both cooked waste, tea waste produce more amount of biogas as compared to cow dung.

\section{REFERENCES}

[1] Singh Bikash, "Assam wants tea waste sale through auction centre," ET Bureau, 2009.

[2] Wasewar, K.L., Mohammad, A, Prasad, B., Mishra, I.M., "Batch adsorption of zinc on tea factory waste," vol. 244, pp. 66-71, 2009.

[3] Huang, J.J.H., and Shih, J.C.H., "The potential of biological methane generation from chicken manure," Biotechnol, Bioeng, vol. 23, pp. 2307-2314, 1981.

[4] Aubart, Ch. and Bully, F., "Anaerobic digestion of rabbit wastes and pig manure mixed with rabbit wastes in various experimental conditions," Agric. Wastes, vol. 10, pp. 1-13, 1984.

[5] Hills, D.J. \& Ravishanker, P., "Methane gas from high solids digestion of poultry-manure and wheat straw," Poultry Sci., vol. 63, pp. 1338-1345, 1984.

[6] Demeyer, A., Jacob, F., Jay, M., Menguy, G, and Perrier, J., "La Conversirn Bioenerg tica de la Radiaci6n Solary las Biotecnologias," Alhambra, 1985.

[7] Lane, A.G., "Methane production and waste management by anaerobic digestion," ASEAN FoodJ, vol. 1, pp. 55-61, 1985.

[8] Sung et al., "Ammonia inhibition on thermophilic anaerobic digestion," Chemosphere, vol. 53, pp. 43-52, 2003.

[9] Gavala et al., "Mesophilic and thermophilic anaerobic digestion of primary and secondary sludge. Effect of pretreatment at elevated temperature," water research, vol. 37, pp. 4561-4572, 2003. 
[10] Demirel et al., "Ammonia inhibition in anaerobic digestion: A review," Process Biochemistry, vol. 48, pp. 901-911, 2013.

[11] Wang et al., "Ammonia inhibition on hydrogen enriched anaerobic digestion of manure under mesophilic and thermophilic conditions," water research, vol. 105, pp. 314-319, 2016.

[12] Ahring et al., "Effect of free long chain fatty acid on thermophilic anaerobic digestion," applied microbiology biotechnology, vol. 37, pp. 808-812, 1992.

[13] Zeshan et al., "Effect of $\mathrm{C} / \mathrm{N}$ ratio and ammonia-N accumulation in a pilot-scale thermophilic dry anaerobic digester," Bioresource Technology, vol. 113, pp. 294-302, 2012.

[14] Palatsi et al., "Long-chain fatty acids inhibition and adaptation process in anaerobic thermophilic digestion: Batch tests, microbial community structure and mathematical modelling," Bioresource Technology, vol. 101, pp. 2243-2251, 2010.

[15] Yadvika, Yadav, A. K., Sreekrishnan, T.R., Satya, S., Kohli, S.March, "A modified method for estimation of chemical oxygen demand for samples having high suspended solids," Bioresource Technology, vol. 97, pp. 721-726, 2006.

[16] Taherzadeh, M. J.and Karimi, K., "Pretreatment of Lignocellulosic Wastes to Improve Ethanol and Biogas Production: A Review,” Int. J. Mol. Sci., vol. 9, pp. 1621-1651, 2008.

[17] Nijaguna, BT., "Biogas technology," New Delhi, New age publication, 2002.

[18] Fan et al., "A Large Terrestrial Carbon Sink in North America Implied by Atmospheric and Oceanic Carbon Dioxide Data and Models," vol. 282. no. 5388, pp. 442-446, 1980.

[19] Melis P and Castaldi P., "Thermal analysis for the evaluation of the organic matter evolution during municipal solid waste aerobic composting process," Thermochim. Acta, vol.413, pp. 209-214, 2004.

[20] Otero M, Calvo L.F, Estrada B, García A.I. and Morán A, "Thermogravimetry as a technique for establishing the stabilization progress of sludge from wastewater treatment plants," Thermochim. Acta, vol. 389, pp. 121-132, 2002.

[21] Halder N., "thermophilic biogas digester for efficient biogas production from cooked waste and cow dung and Some Field Study,” International journal of renewable energy research, vol.7, pp. 1062-1073, 2017.

[22] ANSYS FLUENT user guide. 